\title{
The Development of Service Learning Management Model of Undergraduate Program in Private University
}

\author{
Taneenart Na Soontorn ${ }^{1, *}$ \\ ${ }^{1}$ Philosophy and Education College in Saint John's University, Bangkok, Thailand \\ *Correspondence: Philosophy and Education College in Saint John's University, Bangkok 10900, Thailand. E-mail: \\ medtanee@stjohn.ac.th
}

Received: August 13, 2018

Accepted: September 5, 2018 Online Published: October 12, 2018

doi:10.5430/wje.v8n5p97

URL: https://doi.org/10.5430/wje.v8n5p97

\begin{abstract}
The objectives of research are to develop, identify the main components of "Service Learning Management (SLM)" model, and to assess, evaluate the performance achievement of SLM implementation for undergraduate program in private university. The process of research is divided into two parts as: 1). developing the questionnaire samples that will be distributed to 377 lecturers in private university as the respondents for finding the appropriateness of main components in SLM model by applying the Multi-Stage Sampling; and 2) testing and evaluating the SLM model's effectiveness that will be executed to 11 students in Bachelor of Arts (Major: English for International Communication) of Saint John's University, who registered ENG. 3202 (Introduction to Speech Communication) as a subject in semester 2/2016. The research findings are described the SLM model that consists of 4 major variables and 9 sub-variables as: 1) 'Input' has the 3 sub-variables (Integrated curriculum and instruction; learning outcomes determining; and resource management); 2) 'Process' includes 6 sub-variables that can be classified in to 5 steps (Investigation: lets the community set the requirement; Preparation: is the cooperation of three sides - university, student and community; Execution: is having positive relationship with community; Reflection: continuously evaluating; and Demonstration: is public relations and publicity; 3) 'Output' is the outcomes of learners and results of the evaluation; and 4) 'Feedback' is applying and integrating the outcomes of student's accomplishment and evaluation. The results of demonstration and evaluation of SLM reflection to student performance achievement revealed that 80 percent of students had higher GPA (Grade Point Average), and the learning outcome of students according to Thailand Qualifications Framework (TQF) is considered as high. The results of leadership competency, disciplinary and voluntariness of self-assessment test are counted as high in all aspects. Reflection record can development critical thinking Finally, the overall satisfaction grading by university is considered as high in all aspects, and also the community responses have more advantage benefits and positive impacts in all aspects.
\end{abstract}

Keywords: learning management, service learning, social responsibility

\section{Introduction}

\subsection{Learning Management Change}

In $21^{\text {st }}$ Century is the time that the world has to face rapid changes and unlimited information. Moreover, there are more channels to seek for knowledge. Hence, it is a must for education to be changed in relation to the learning atmosphere and ethical indoctrination to create the appropriate behavior for students that cannot be achieved by learning in classroom alone (Juree \& Wimonratt, 2009). The result of the current instruction must focus on self-study of learners by building the creativity, synthetically analytic thinking, communication skills (listening, writing and reading) and ability to work with other people such as community and society so that students will realize the coexistence in society and help to solve social problems that impacts the coexistence of people in the society. As lecturer's role will be changed from one-sided teaching to exchanging knowledge with the students, lecturers have to adjust themselves to be counselor and providers of the new learning style which emphasizes on activity that serves as the knowledge exchange to build the self-study knowledge creation and integrating technology into learning process in order to improve the quality of education (Tissana, 2007). 


\subsection{Service Learning}

Service Learning is a type of learning that connects to social awareness and has highest efficiency, because the learners get to realistically participate to use their experiences to serve the society. This is corresponding to Progressivism proposed by Dewey (1938) which focuses on the process of learning by doing or gaining realistic experiences. Thus, service learning is considered as the valuable experiences towards social services according to the needs of community which is not only beneficial for the community, but also inspires and encourages the learners to serve society (Tissana, 2007).

\subsection{Thailand Qualifications Framework (TQF) with the Learning Management System}

Government of higher education and private university of Thailand also created the learning management system which separates the section of studies, and allows the students to choose their curriculums according to the subjects that they want to attend. By doing this, students may graduate after finishing every course without a requirement to experience and connect to the situation outside their classrooms. Furthermore, this learning style does not apply the reality of society to the instruction. It only emphasizes on the lectures not the thinking. Therefore, Thai education system cannot shape citizens to be responsible for the society as it should. To solve this education issue, Thai education has to shift from being input-based education to be outcome-based education by implementing student-centered learning. Moreover, as the one who is in charge of lecture, which is an activity that leads students to the results, lecturer needs to change from only giving lecturing to providing the activities that let the students participate such as learning from occurred problems, learning from projects, and learning from serving the society. These given activities are all activity-based learning which is the learning method of outcome-based learning. Hence, lecturer has to get the supporters from three parties:

(1). University - supports lecturer by executing policies, providing resources, and being liaison,

(2). Student - supports lecturer by appreciating knowledge, skills and experiences that cannot be attained from classroom and

(3). Community - supports lecturer by cooperating to reflect the actual problems and solve them. If three sides cooperate with one another properly, service learning management will be developed efficiently (Prinya, 2016).

The important of this research is to adapt a learning management form by giving a lecture to be workshop or practical form. Therefore, the results from this research may aim to affect to the characteristic of graduate in both academic and desirable.

\subsection{Research Objectives}

1. To develop and identify the main component of Service Learning Management (SLM) model for undergraduate program in private university.

2. To pre-test and evaluate the model effectiveness of service learning management reflected to the student performance achievement of undergraduate program in private university.

\subsection{The Benefits of Research}

1) This research can be applied in the integration of learning management with academic services to society.

2) They can be used to organize student development activities for leadership, discipline, and social responsibility and volunteerism.

\section{Method}

\subsection{Population and Sample}

The population of this research are 11,006 lecturers in 68 private universities in Thailand. The Multi-Stage Sampling was applied to get the sample of 377 respondents. The tool used to collect data is 5-point Likert scale questionnaire which can measure the reliability of variables of service learning management (Boonreng, 2000). Every variable has values of index of item-objective congruence higher than 0.5, and Cronbach's Apha Coeffient at 0.97. The percentage frequency distribution analysis is done by selecting the questions that have high-to-highest feasibility level (80\% or above).

Data analysis were used frequency, percentage, mean and standard deviations, then the mean comparison of GPA scores of students with the standard of $80 \%$; lastly for the analysis of benefit and impact assessment towards the frequency analysis. 


\subsection{Measures and Covariates}

Testing tools were:

1) Questionnaire;

2) GPA survey corresponding to Thailand Qualifications Framework (TQF);

3) Self-administered leadership proficiency, punctuality and volunteer spirit survey;

4) Reflection record

5) Satisfaction questionnaire for social academic service committees; and

6) Benefit and impact evaluation form of academic services for community (based on the representative sampling sites conducted in Jatujak Market, Bangkok) that has index of item-objective congruence value higher than 0.5 for all aspects.

\subsection{Research Framework}

The principles and theories of system approach used service learning and five stage of service learning: a dynamic process and then synthesized into the main components of service learning management model which includes 9 variables (Nasoontorn, 2018) as they can be seen in the conceptual framework shown in figure 1.

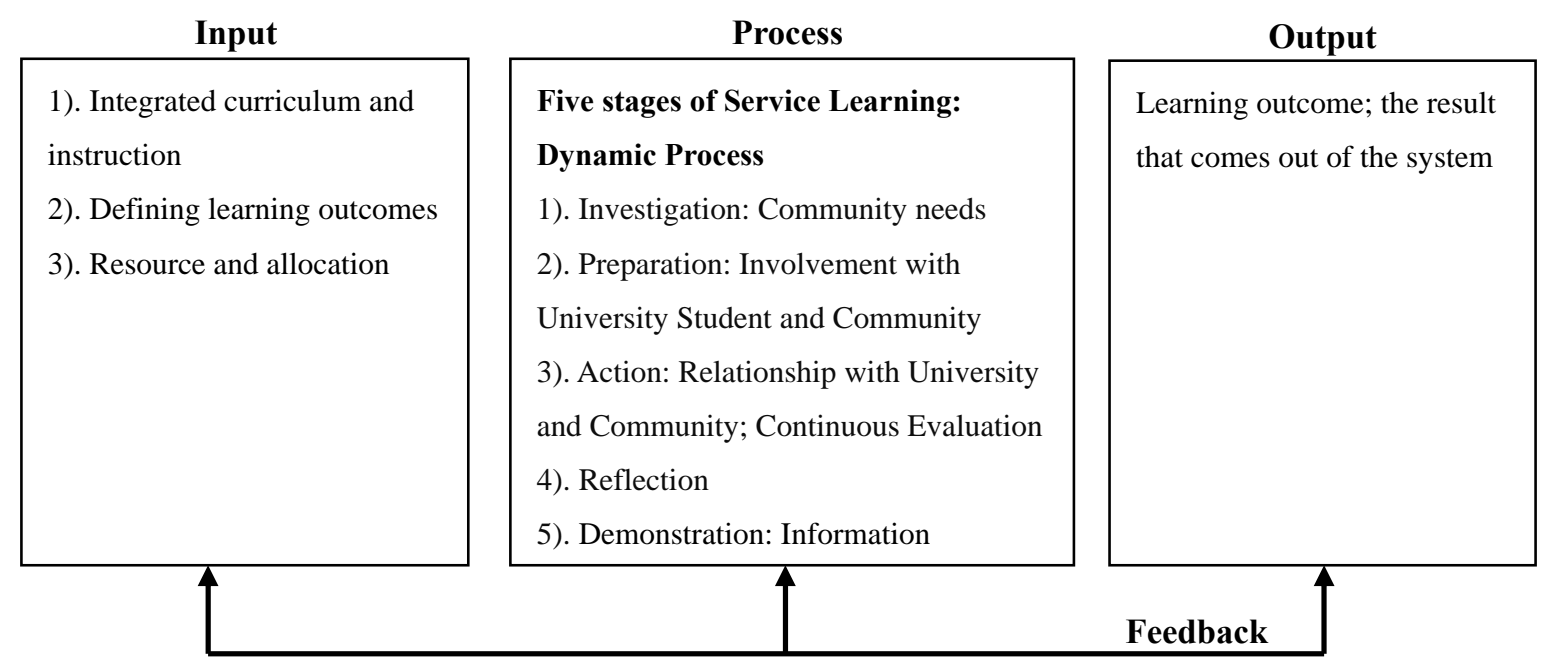

The improvement of student's achievement and system evaluation of model

Figure 1. Conceptual Framework of SLM Model and 9-Main Components

\subsection{Research Design}

There are 2 steps as follows:

Step 1: Developing and identifying the main components of SLM model (Divided into 2 sub-steps are shown below) as:

1. Study journals that are related to managing and establishing service learning in order to construct the conceptual framework of SLM. Then, conduct the focus group with 7 experts who have experiences in service learning management.

2. Interrogate the reliability of variables that are directly related with the service learning management.

Step 2: Pre-test and evaluate the model of service learning management by implemented to the Bachelor of Arts' student in Saint John's University in semester 2/2016 for 8 weeks from 9.00 am to 4.00 pm as one group posttest design. The population used in this test are 11 Bachelor of Arts in English for International Communication students of Saint John's University, who registered ENG. 3202 (Introduction to Speech Communication) as a subject in semester 2/2016 via using the learing process of five stage of service learning : a dynamic process (Cathryn Berger Kaye, 2010) 


\section{Results}

\subsection{Demographic Information}

The questionnaire had been sent out to the sample 377 copies and returned back to 300 copies (79.57\%). In the demographic information section, most respondent aged between $40-50$ years (34\%). Their education were master degree 198 people (66\%) which also have gained teaching experience more than 15 years 112 people (37.3\%). In sum up, most of important respondents were a lecturer in private universities aged not over than 50 years, qualification in master degree, and having teaching experience more than 15 years.

3.2 The Model of Service Learning Management of Undergraduate Students in Private University Consists of 4 Major Variables and 9 Sub-Variables as Shown in Table 1

Table 1. The model of Service Learning Management of Undergraduate Students in Private University

\begin{tabular}{|c|c|c|c|}
\hline Variables & \multicolumn{3}{|l|}{ Sub-variables } \\
\hline \multirow[t]{3}{*}{ Input } & \multicolumn{3}{|l|}{ 1). The integrated curriculum and academic activity. } \\
\hline & \multicolumn{3}{|l|}{ 2). Expectation of learning outcomes and } \\
\hline & \multicolumn{3}{|l|}{ 3). Resources and allocation management. } \\
\hline \multirow[t]{6}{*}{ Process } & \multicolumn{3}{|l|}{ Five stages of service learning: a Dynamic process as follows: } \\
\hline & \multicolumn{3}{|c|}{$\begin{array}{l}\text { 1). Investigation: Community sets the requirements as: activity: seeking for the community anc } \\
\text { let it set the requirement. }\end{array}$} \\
\hline & \multicolumn{3}{|c|}{$\begin{array}{l}\text { 2). Preparation: The cooperation from } 3 \text { parties (university, student, and community) whic } \\
\text { consists of } 4 \text { activities as: Classifying student into group / Communication practice / Case stud } \\
\text { and / Orientation before action. }\end{array}$} \\
\hline & \multicolumn{3}{|c|}{$\begin{array}{l}\text { 3). Action: Building good relationship with community and continuous evaluation that includes } \\
\text { activities as: Coordinating with community / Providing service to the location to build goo } \\
\text { relationship with community / Continuous evaluation. }\end{array}$} \\
\hline & \multicolumn{3}{|c|}{ 4). Reflection: Includes one activity which the reflection activity for students. } \\
\hline & \multicolumn{3}{|c|}{$\begin{array}{l}\text { 5). Demonstration: Press and publish for students include } 2 \text { activities as: Students publishing } \\
\text { their masterpieces on board and publicizing them and / Faculties publicizing the process of } \\
\text { building attributes of students via media. }\end{array}$} \\
\hline Output & \multicolumn{3}{|l|}{ The achievement of student and system evaluation result. } \\
\hline Feedback & \multicolumn{3}{|c|}{ Integrating the achievement of student and system evaluation result into the model. } \\
\hline \multicolumn{4}{|c|}{$\begin{array}{l}\text { All variables have high-to-highest level of feasibility (above } 80 \% \text { ). Also, the average of student's acaden } \\
\text { achievement is higher than the standard (above } 80 \% \text { ) too. }\end{array}$} \\
\hline \multicolumn{4}{|c|}{$\begin{array}{l}\text { 3.3 The Overall and Separated Sections of Student'S Academic Achievement Corresponding to Thailar } \\
\text { Qualifications Framework are Ranked as High (shown in Table 2). }\end{array}$} \\
\hline \multicolumn{2}{|c|}{ Academic Achievement Corresponding to Thailand Qualifications Framework } & $\overline{\mathbf{x}}$ & S.D. \\
\hline \multicolumn{2}{|c|}{ Responsibility and interpersonal relationship skills } & 3.78 & .34 \\
\hline \multicolumn{2}{|l|}{ Ethics } & 3.71 & .23 \\
\hline \multicolumn{2}{|c|}{ Knowledge } & 3.67 & .27 \\
\hline \multicolumn{2}{|c|}{ Intelligence } & 3.63 & .25 \\
\hline \multicolumn{2}{|c|}{ Numerical analysis, communication and technology } & 3.57 & .44 \\
\hline \multicolumn{2}{|c|}{ Overall } & 3.67 & .26 \\
\hline
\end{tabular}


3.4 Overall and Separated Section of Volunteering Self-Evaluation in Terms of Leadership, Discipline and Social Responsibility Rated by Students as High (Shown in Table 3).

Table 3: Student's Volunteering Self-Evaluation

\begin{tabular}{lcc}
\hline Volunteering & $\overline{\mathbf{x}}$ & $\mathbf{S . D .}$ \\
\hline Leadership & 3.76 & .16 \\
Discipline & 3.68 & .21 \\
Social Responsibility & 3.76 & .20 \\
Overall & 3.74 & .16 \\
\hline
\end{tabular}

3.5 The Academic Service Committee of Saint John's University Ranked the Satisfaction Towards Service Learning Management Model as High (shown in Table 4).

Table 4. Academic Service Committee’S Satisfaction Towards Service Learning Management Model

\begin{tabular}{lcc}
\hline Satisfaction level of Service Learning management model & $\overline{\mathbf{x}}$ & $\mathbf{S . D .}$ \\
\hline Input & 3.49 & .51 \\
Process & 3.55 & .50 \\
Output & 3.62 & .49 \\
Feedback & 3.62 & .49 \\
Overall & 3.57 & .50 \\
\hline
\end{tabular}

3.6 Jatujak Market Community Committee of Saint John's University Evaluated Benefits and Impacts of Social Academic Service as Seen on Table 5.

Table 5. Jatujak Market Community Committee of Saint John's Benefits and Impacts of Social Academic Service Evaluation

\begin{tabular}{lcc}
\hline Benefits and impacts of social academic service & Frequency & Percentage \\
\hline $\begin{array}{l}\text { 1. Community-based project } \\
\text { 2. Community can use the knowledge and benefits from participating in this } \\
\text { project }\end{array}$ & 10 & 100 \\
3. Knowledge provided by the project has positive and realistic effect on & 3 & 100 \\
community which creates the information exchange culture & 30 & 30 \\
4. Cooperation network is established & 3 & 40 \\
5. The project is beneficial for financial income & 10 & 100 \\
7. The project has positive impact towards community & 10 & 100 \\
\hline
\end{tabular}

\section{Discussions}

1. Service Learning management model of undergraduate student in private university consists of 4 main elements and 9 sub-elements which are appropriate for service learning management as systematic management concept combines every element that is related to one another to manage and proceed in order to reach learning's objectives (input, process, output and feedback). As university's role is to create graduates and desirable attributes for students as required, it is necessary to set the policy from the level of university council to university in order to connect to the subject management for department level and curriculum level. Once all parts are synchronized throughout the whole system, long-term, mid-term and annual plans are set to manage resource for the support by coordinating both insiders and outsiders of university to jointly create the proper attributes of students. Systematic management will help to analyze each section from external factor, production process, output and feedback as stated in the study of (Kongkiat \& Krismant, 2016) and the service learning development. Results of course project for industrial technician student revealed that instruction style that was developed from system approach includes 5 major elements which are 1) input, 2) process, 3) control, 4) production and 5) feedback, and 12 sub-elements which are 1) setting the target for the instruction 2) student analysis 3) lesson designing 4) learning activity planning 5) instruction resource selection and development 6) appointing the role of lecturer 7) learning encouragement and inspiring 8) service learning procedure 9) monitoring and controlling the quality of student's learning 10) examination during 
class 11) teaching effectiveness 12) gaining feedback to adjust the evaluation. According to experts, the model was stated to be the most appropriate since student's grading achievement is higher than $80 \%$ as its statistical significance is at 0.1 . This means the level of the acceptance survey of community towards innovation is ranked as very high.

2. Student's academic achievement was higher than $80 \%$, because this style of learning let students act in the real situation to help tourists in Jatujak market. Students had to use their thinking skills to serve and solve the problems by themselves as they need to cooperate with community and have leadership skills. This is consistent to the research of Juree and Wimonratt (2009) about the application of learning techniques towards social services in vocational school: 1) student's academic achievement is higher than $80 \%$ 2) Students have high attitudinal standard in terms of enthusiasm and collaboration 3) the desirable behavior of student is rated as very good 4) the service achievement of community is ranked as very good.

3. The overall and separated section of academic achievement of student corresponding to Thailand Qualifications Framework were rated to be in the high level which means the students had developed skills from cooperating with others according to the research of Lori Simons and Beverly Cleary (2010) about the Influence of Service Learning on Students' Personal and Social Development. The study found that students had developed different aspects of knowledge and effectively gained political and community awareness by themselves as there was the participation scores from the beginning of the semester to the end of the semester. In addition, personal development, interpersonal relationship and community commitment were important benefits from attending service learning.

4. The overall and separated section of student's evaluation in leadership, discipline and responsibility towards society were rated as high. This represents the behavior of student when facing issues of service providing, planning and assigning responsibility, and service evaluation according to the theory proposed by Mary (1998) that showed the management of Model of Good Practice for Service-Learning Program by specifying on students' supports towards community to create their leadership skills. Students are important for community's learning and project design. Many universities that have great students played important roles as to get the academic scholarship from the community, be coordinators for sponsors, be lecturers, and become the leader of project.

5. The separated section and overall satisfaction of student towards Service Learning management were ranked as highest which was resulted from the change of learning style from classroom to real situation through abundant projects that students were interested in. The reflection could improve the knowledge, skills and attributes for students. Thus, process of curriculum design and learning activity arrangement is the first process that lectures and accomplices should well plan according to the theory of Weigert (1998) as stated that it was the teaching that students participated in service learning activity to response to the problems and needs of society in order to accomplish the course's objectives which were systematically prepared, and integrated into the curriculum and courses by considering the action through learning. Additionally, this had to be evaluated and measured academically and socially.

6. The overall and separated section of the satisfaction of service learning committees of Saint John's University was ranked as high. It shows that the committees had realized the positive changes of students in terms of the cooperation between university, student and community from the beginning to the end of the project. The outcome is significant that this project could develop academic knowledge, shape the personal characteristics, encourage people to realize their responsibilities towards society as posited in the study of Judith (2006) about The Effect of Community Service Work on Moral Development of College Ethics Student which was the result of providing services to community of students, university of ethics and activity design. The test of impacts of community's service revealed that providing services for community and morality discussion were the most effective methods. By presenting the ethical reason in the conference, students could reflect their understanding and knowledge of community's service providing and community's benefits.

\section{Recommendations and Further Study}

1. The process of integration of curriculum and learning management is the most important for service learning. Lecturers are an important mechanism to motivate student to be interested, pay attention to the issued of community. This allows the student to experience problems by themselves which leads to building the thinking process for students.

2. University should assign the positive-minded primary coordinator who realizes the benefits and values from service learning to coordinate and create good relationships between university, student and community.

3. Community is an important learning source for university and student. Therefore, the cooperation of community is 
necessary for service learning. If community understands the values and benefits of cooperation well, the learning will result positively and benefit the creation of graduates of university.

4. Lecturer is an important mechanism. Thus, private university lecturer should conduct the research about developing training course for service learning management.

\section{Acknowledgments}

I would like to extend cheers to the many people, in many departments from my university, who so generously contributed to the work presented in this research. Special mention goes to my enthusiastic supervisor and the president of Saint John's University, Dr. Chulakasem Chinnapha. I thank Dr. Chulakasem for his tremendous academic support, but also for giving me so many wonderful opportunities. Similar, profound gratitude goes to Dr. Boonreng Kajornsin, Dr. Pimprapa Amornkitpinyo and Dr. Thanyatorn Amornkitpinyo who has been a truly dedicated consultant and mentor. I am particularly appreciative to Dr. Chompu Nuangjamnong and Dr. Bhakhakanok Ratanawaraphorn for their support and encourage. Next, I also thank you all specialists, leader of Chatuchak market, former collegue Arjan Darunee Meechai, and all students from Liberal Arts Faculty in major of English

Communication. Finally, but by no means least, thanks go to Dr. Sunthorn Poolpipatana for almost unbelievable support. They are the most important people in my world and I dedicate this research to them.

\section{References}

Boonreng, K. (2000). Educational Research Methodology. (5th ed.). Bangkok press.

Cathryn Berger Kaye. )2010). The Five Stages of Service Learning: A Dynamic Process. CBK Associates, International Education.

Dewey, J. (1938). Experience and Education. NewYork: Macmillan.

Eyler, J. (2002). Reflection: Linking service and learning - Linking students and communities. Journal of Social Issues, 58(3), 517-534. https://doi.org/10.1111/1540-4560.00274

Forgarty, R. (1997). Problem-based learning and other curriculum models for the multiple intelligences classroom. IL: Glenview.

Jacoby, B., \& Associates (Eds). (1996). Service-learning in higher education: Concepts and practices. San Francisco: Jossey-Bass Publisher.

Judith A. Boss. (2006). The Effect of Community Service Work on Moral Development of College Ethics Student. Retrieved from www.tandfonline.com/doi/abs/

Juree, T., \& Wimonratt, J. (2009). Implementing Service Learning in Vocational Education. Journal of Educational Development and Social Development, 5, 1-2.

Kongkiat, T., \& Krismant, W. (2016). Development of A Service Learning and Teaching Model for a Project Course of Industrial Education Student. Dissertation Doctor of Philosophy. Department of Educational Technology Faculty of Education, King Mongkut's University of Technology North Bangkok.

Lori, S., \& Beverly, C. (2010). The Influence of Service Learning on Students's Personal and Social Development. Retrieved from https://www.tandfonline.com/doi/abs/

Mary, Kay. S. (1998). Models of Good Practice for Service Learning Program. AAHE BULLETIN /JUNE, 1988/11

Mintz, S.D., \& Hasses, G. W. (1996). Principles of good practice in service learning. San Francisco: Jossey-Bass Publisher.

Nasoontorn, T. (2018). UCS-Service Learning Model: A student development to Thailand 4.0. Bangkok: Chulalongkorn University Press.

Prinya, T. (2016). Education for Citizenship (2nd ed.). Bangkok: Thammasat University.

Tissana, K. (2007). Teaching Knowledge to Effective Learning Process. Bangkok: Chulalongkorn University Press.

Weigert, K. M. (1998). Academic Service Learning: Its Meaning and Rebevance. New Directions for Teaching and Learning, 73, Spring: Jossey Bass Publishers. https://doi.org/10.1002/tl.7301 